Ann. Génét. Sél. anim., I969, 1 (4), 439-446.

\title{
SOME THOUGHTS ON THE ASSOCIATION OF POLLED TRAIT AND INTERSEXUALITY IN GOATS
}

\author{
Parvathi-K. BASRUR \\ Department of Biomedical Sciences \\ University of Guelph \\ Guelph, Ontario, Canada
}

SUMMARY

A cytogenetic mechanism for the association of polledness and intersexuality in dairy goats has been proposed in the light of the existing information on intersexes and sex determination. On the basis of the marked sexual dimorphism for horn in the more primitive members of Bovidae and the strong androgen dependence exhibited by the cephalic adornments in general, it is proposed that the determinant of horn in the ancestral species of Goats was located on the $\mathrm{Y}$ chromosome in close proximity to, or as part of the maledetermining genes. The presence of horn in females in the more recent species of Bovidae has been attributed to the translocation of a Y chromosome segment to an autosome. According to this hypothesis the development of the horn anlage and the specialization of the somatic blastema cells into Leydig cells of the testes are probably controlled by the same gene (or genes) which were translocated from the $Y$ chromosome to an autosome during the course of evolution in the Caprinae subfamily.

The hypotheses advanced by various investigators in the past for the occurrence of intersexuality in polled goats have been adequately discussed by LAUVERGNE in this symposium. In this report an attempt is made to postulate a cytogenetic mechanism for the association of polled trait and intersexuality in dairy goats.

Mc FEELY, et al. (r967) have suggested that sex determination in Mammals including goats may be explained on the basis that the male determining gene on the $\mathrm{Y}$ chromosome has its homologue on the $\mathrm{X}$ chromosome and that it stays repressed in the normal female due to the presence of two $\mathrm{X}$ chromosomes while it is derepressed by the $\mathrm{Y}$ chromosome in the normal male. This hypothesis thus presupposes that the structural gene for male determination is on the $\mathrm{X}$ chromosome and that its expression in some way, is controlled by the $\mathrm{Y}$ chromosome. The occurrence of intersexuality in homozygous polled female goats accord- 
ing to these investigators (Mc FEELY, et al., 1967) is related to the fact that the male determining gene on the $\mathrm{X}$ is derepressed by the gene for polled $(P)$. $\mathrm{HA}_{\mathrm{A}}$ MERTON, et al., (I969) supports this hypothesis in essence and further postulates that the degree of intersexuality in these animals may be dependent on the amount of medullary or cortical tissues which, in a developing gonad, may be influenced by the sex chromosomes. This hypothesis (HAMERTON, et al. I969) as that of MCFEELY et al. (I967) implies that the polled gene in homozygous state is capable of exerting a $\mathrm{Y}$ chromosome-like influence on the developing gonad. The emphasis on medulla and cortex as the sex determining factors reflects OHNo's view ( 1967 ) that the phenomenon of sex determination is dependent on the hormone-producing somatic cells of the developing gonad and that the actual time of expression of the "sex determining genes " may be when the mesonephric blastema cells make the decision to migrate either to the cortex or to the medulla of the indifferent gonad to become, respectively, the follicle cells of the ovary or the Leydig cells of the testis (OHNo, I967). It has also been demonstrated that the somatic elements for both types of gonads and the precursors of the adrenal cortical cells originate from a common blastema (OHNO, I967). Our studies on intersex goats (BASRUR and KANAGAWA; This Symposium) have shown that the hypoplasia frequently noted in the testes of intersex goats (SOLLER et al., I969; HAMERTon, et al., r969; BASRUR and Coubrough, I964; BASRUR and KANAGAWA, I968) is also evident in the adrenal cortex of these animals. It would appear that the migration and/or the subsequent fate of the mesonephric blastema cells is influenced by the polled genes in genetic females. Studies on the hydroxysteroid dehydrogenase activity of the goat adrenals have indicated (BAsRur and Kanagawa, This Symposium) that the biosynthesis of the androgenic steroids in intersex goats is comparable to that in normal adult goats. In other word, the differentiation of the adrenal cortical cells and the somatic cells of the gonads have followed the male direction in these intersexes in the apparent absence of a $Y$ chromosome.

Malesex-differentiation in a majority of Mammals has been shown to be dependent on the presence of a $Y$ chromosome (WELSHONS AND RUSSELL, I959; Jacobs AND Strong, r959, OHno, I967) although variation in the size and number of $\mathrm{Y}$ has been reported to have no apparent bearing on maleness (OHNo, I967). It is very likely that the $\mathrm{XX}$ goats carry some male determining genes. A hypothesis that accommodates this assumption is that in the ancestral forms of goats the gene controlling the development of horns may have been located on the $Y$ chromosome along with the male determinants and that a part of this $\mathrm{Y}$ chromosome during the course of evolution got translocated to an autosome which we now recognize as that carrying the gene for horn.

Horns are unmistakably associated with the secondary sexual characteristics in some of the subfamilies of Bovidae. A cursary look at the distribution of horn in members of various subfamilies of Bovidae (DRIMMER, I954) in the light of their systematic position indicates that in a majority of the more " primitive "species of Bovinae, Hippotraginae and Strepsiserotini the females are hornless. It would appear that in these species the gene for horns was carried by the $\mathrm{Y}$ chromosome. Alternatively one could assume that horn development 
TABLE I

Distribution of horns in some of the subfamilies of Bovidae

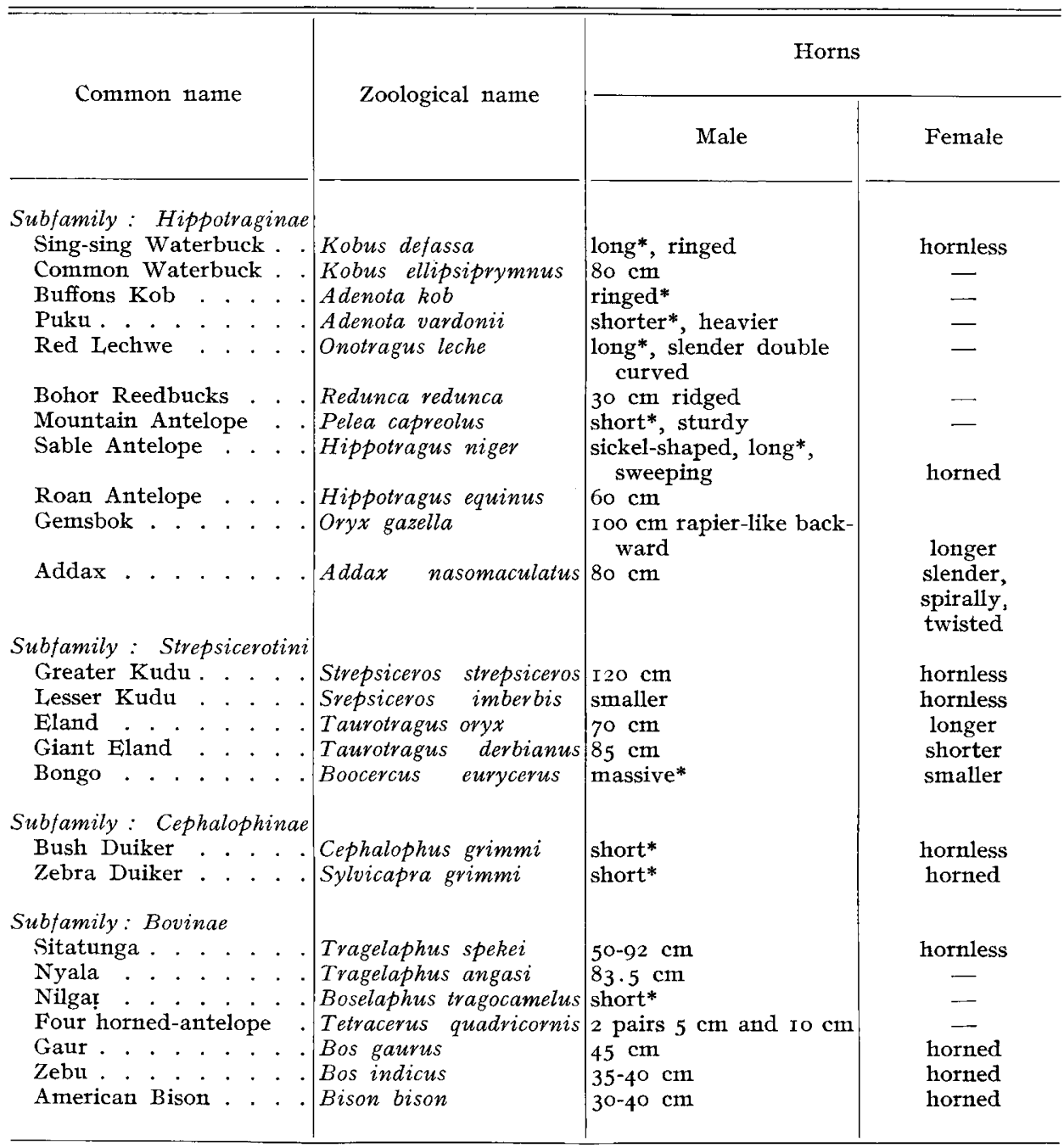

* Exact size not known.

in these animals was, as is the development of the accessory sex organs in most Mammals (JoST, I957), a concommittant of testicular development and the elaboration of male hormones. In Cervidae, a family closely related to Bovidae, cephalic adornments such as antlers have been clearly shown to be androgen dependent (MODEL, I969). Wether a single gene is involved in male determination or a group of genes each controlling a specific aspect of male development, is not known. The various aspects of normal male differentiation include (I) the specialization of the somatic cells of the indifferent gonad into Leydig cells 
(2) the stabilization and further elaboration of the Wolffian ducts to give rise to the male accessory sex organs, (3) the inhibition of the Mullerian duct system and (4) the differentiation of male type external genitalia. The last three aspects have been considered androgen dependent and thus controlled by the activities of the androgen-producing cells of the developing testes (JosT, I947; NEumanN, et al., I969). It is possible that in species of Bovidae in which the horns were restricted to males, the development of horn anlage was also dependent on fetal androgen which in turn was controlled by the male determinants on their $\mathrm{Y}$ chromosome. The sexual dimorphism is less distinct in relatively more recent species belonging to the subfamilies of Bovidae and it is barely detectable in taxonomically more recent sub-families including Caprinae. The chromosome feature and the distribution of horn in the txo sexes of Caprinae and the related subfamilies Antilopinae and Bovinae are presented in Tables 2, 3 and 4 . The cytogenetic make-up of Bovidae has been considered to be remarkably stable since in a majority of subfamilies the "nombre fondamental " (the number of chromosome arms) is 60 (WURSTER and BENIRSCHKE, I968). The variation in diploid number noted between individual species of Bovidae could easily be traced to Robertsonian rearrangements (HECk, WURSTER and BENIRSCHKE, I968). The sex complements in Caprinae are distinct from the members of the other subfamilies of Bovidae (Tables 2 and 3 ) in that, in a majority of species of Caprinae (Table 4), the $\mathrm{X}$ chromosome is a large acrocentric and the $\mathrm{Y}$ chromosome is a small metacentric (BASRUR and STOLTZ, I967; WURSTER and BENIRSCH KE, I968).

TABLE 2

Description of the horns and sex complements in members of the family Bovidae: Subfamily: Bovinae

\begin{tabular}{|c|c|c|c|c|c|c|}
\hline \multirow{2}{*}{$\begin{array}{l}\text { Zoological Name } \\
\text { and } \\
\text { Common Name }\end{array}$} & \multicolumn{2}{|c|}{ Description of Horns } & \multicolumn{4}{|c|}{ Chromosomes } \\
\hline & Male & Female & $2 n$ & $\mathrm{NF}$ & $\mathrm{x}$ & $\mathrm{Y}$ \\
\hline $\begin{array}{l}\text { Tragelaphus spekei } \\
\quad \text { Sitatunga }\end{array}$ & $\begin{array}{l}50.8-92.4 \mathrm{~cm} \\
\text { spiral }\end{array}$ & Hornless & 30 & $5^{8}$ & $x l \mathrm{M}$ & $x l \mathrm{M}$ \\
\hline $\begin{array}{l}\text { Tragelaphus angasi } \\
\text { Nyala }\end{array}$ & $83.5 \mathrm{~cm}$ & - & 55 & $5^{8}$ & ? & $?$ \\
\hline $\begin{array}{l}\text { Boselaphus Tragocamelus } \\
\text { Nilgai }\end{array}$ & short* & - & 46 & 60 & $l \mathrm{M}$ & IA \\
\hline $\begin{array}{c}\text { Tetracerus Quadricornis } \\
\text { Four-horned antelope }\end{array}$ & $\begin{array}{l}2 \text { pairs, } \\
(5 \mathrm{~cm} \text { and } 10 \mathrm{~cm})\end{array}$ & - & $3^{8}$ & $3^{8}$ & $m \mathrm{~A}$ & $s \mathrm{M}$ \\
\hline $\begin{array}{l}\text { Bos gaurus } \\
\text { Gaur }\end{array}$ & $45 \mathrm{~cm}$ & Horned & $5^{8}$ & 62 & $l \mathrm{M}$ & $s \mathrm{M}$ \\
\hline $\begin{array}{l}\text { Bos indicus } \\
\text { Zebu }\end{array}$ & $35-40 \mathrm{~cm}$ & Horned & 60 & 62 & $l \mathrm{M}$ & $s \mathrm{~A}$ \\
\hline $\begin{array}{l}\text { Bison bison } \\
\text { American Bison }\end{array}$ & $30-40 \mathrm{~cm}$ & Horned & 60 & 62 & $l \mathrm{M}$ & $s \mathrm{~A}$ \\
\hline
\end{tabular}

* Exact size not known; $2 n$ : Diploid Number; NF : Nombre Fondamental; A : Acrocentric; M : Metacentric; $x l$ : Extra Large; $l:$ Large; $m:$ Medium; $s:$ Small. 
TABLE 3

Description of the horns and sex complements in members of the family Bovidae: Subfamily: Antilopinae

\begin{tabular}{|c|c|c|c|c|c|c|}
\hline \multirow{2}{*}{$\begin{array}{l}\text { Zoological Name } \\
\text { and } \\
\text { Common Name }\end{array}$} & \multicolumn{2}{|c|}{ Description of Horns } & \multicolumn{4}{|c|}{ Chromosomes } \\
\hline & Male & Female & $2 n$ & $\mathrm{NF}$ & $\mathrm{x}$ & $\mathrm{Y}$ \\
\hline $\begin{array}{l}\text { Litocranius reallevi } \\
\text { Waller's Gazelle } \\
\text { Aepyceros melampus }\end{array}$ & $\begin{array}{l}33.5 \mathrm{~cm} \\
\text { ringed, curved } \\
50-75 \mathrm{~cm}\end{array}$ & Hornless & 60 & $\begin{array}{l}60 \\
60\end{array}$ & $l \mathrm{~A}$ & $\begin{array}{l}m \mathrm{~A} \\
s \mathrm{M}\end{array}$ \\
\hline $\begin{array}{l}\text { Impala } \\
\text { Rhynhotragus kirki }\end{array}$ & $\begin{array}{l}\text { ringed, lyre } \\
\text { ringed, stout }\end{array}$ & - & 46 & $4^{8}$ & $l \mathrm{~A}$ ? & $?$ \\
\hline $\begin{array}{l}\text { Kirk's dik dik } \\
\text { Raphicerus campestris } \\
\text { Steinbok }\end{array}$ & $2.5-12.7 \mathrm{~cm}$ & - & 30 & $5^{8}$ & $l \mathrm{~A}$ & $s \mathrm{M}$ \\
\hline $\begin{array}{l}\text { Antilope cervicapra } \\
\text { Blackbuck }\end{array}$ & $\begin{array}{l}45.6-68.5 \mathrm{~cm} \\
\text { spiral ringed }\end{array}$ & - & 30 & 60 & $x l \mathrm{M}$ & $?$ \\
\hline $\begin{array}{l}\text { Gazella thomsoni } \\
\text { Thomson's gazelle }\end{array}$ & $\begin{array}{l}\text { long, curved } \\
\text { with upward swing }\end{array}$ & 一 & $5^{8}$ & $72 ?$ & $l \mathrm{M}$ & $s \mathrm{M}$ \\
\hline $\begin{array}{l}\text { Gazella dama } \\
\text { Dama gazelle }\end{array}$ & $\begin{array}{l}\text { lyre, backward and } \\
\text { upward }\end{array}$ & $\begin{array}{l}\text { absent or } \\
\text { (smaller) }\end{array}$ & $3^{8}$ & 60 & $?$ & $?$ \\
\hline $\begin{array}{l}\text { Antidorcas marsupialis } \\
\text { Springbok }\end{array}$ & lyre, ringed & Horned* & 56 & 60 & $l \mathrm{~A}$ & $s \mathrm{M}$ \\
\hline
\end{tabular}

* Similar to male. $2 n$ : Diploid Number; NF : Nombre Fondamental; A : Acrocentric; M : Metacentric; $s$ : Small; $m$ : Medium; $l$ : Large.

It is interesting to note that among the species of Caprinae so far studied, the $\mathrm{Y}$ chromosome is a medium size acrocentric (WURSTER and BENIRSCHKE, I968) only in Saiga antelope (Saiga tatarica) which also happens to be a species in which the sex dimorphism for horns is maintained. The chromosome make-up of Saiga tatarica, with the exception of the $\mathrm{Y}$ chromosome is remarkably similar to that of the domestic goat and its various relatives belonging to the subfamily Caprinae. Although the taxonomic positions of these species probably have to be confirmed by other means, it is not too far-fetched to assume that in Saiga antelope or in a Saiga-like species of Caprinae, a segment of the $\mathrm{Y}$ chromosome carried the gene for horns, either as part of, or in close proximity to, the male determining genes and that in the course of evolution from this ancestor it was translocated to an autosome. Such a chromosome rearrangement would be the initial step in introducing the horn gene in the females of this subfamily. A dominant mutation $(P)$ affecting this translocated segment, must have been the next step in the course of evolution. This dominant mutation soon became established in the population through goat breeders' enthusiastic selection of hornlessness for their dairy goats. According to this hypothesis, then, the association of polled trait and intersexuality in goats came about in two steps : the translocation of a segment of the $\mathrm{Y}$ chromosome to an autosome in a Saigalike ancestor and a subsequent mutation on this autosome involving this translocated segment. 
TABLE 4

Description of the horns and sex complements in members of the family Bovidae : Subfamily : Caprinae

\begin{tabular}{|c|c|c|c|c|c|c|}
\hline \multirow{2}{*}{$\begin{array}{c}\text { Zoological Name } \\
\text { and } \\
\text { Common Name }\end{array}$} & \multicolumn{2}{|c|}{ Description of Horns } & \multicolumn{4}{|c|}{ Chromosomes } \\
\hline & Male & Female & $2 n$ & $\mathrm{NF}$ & $\mathrm{x}$ & $Y$ \\
\hline $\begin{array}{l}\text { Saiga tatarica } \\
\quad \text { Saiga antelope }\end{array}$ & $\begin{array}{l}20.3-25.5 \mathrm{~cm} \text { lyre } \\
\text { shaped, ringed in } \\
\text { front }\end{array}$ & Hornless & 60 & 60 & $l \mathrm{~A}$ & $m \mathrm{~A}$ \\
\hline $\begin{array}{l}\text { Oreamnos americanus } \\
\text { Rocky mountain goat }\end{array}$ & $\begin{array}{l}20.3-30.5 \mathrm{~cm} \\
\text { dagger-like }\end{array}$ & Horned* & 42 & 60 & $l \mathrm{~A}$ & $s \mathbf{M}$ \\
\hline $\begin{array}{l}\text { Ovibos moschatus } \\
\text { Musk ox }\end{array}$ & $\begin{array}{l}61.0 \mathrm{~cm} \text { massive, } \\
\text { broad and curved }\end{array}$ & - & 48 & 60 & $l \mathrm{~A}$ & $s \mathbf{M}$ \\
\hline $\begin{array}{l}\text { Hemitragus jemlahicus } \\
\text { Himalayan tahr }\end{array}$ & $\begin{array}{l}\text { short and evenly } \\
\text { curved }\end{array}$ & - & $4^{8}$ & 60 & $l \mathrm{~A}$ & $s \mathbf{M}$ \\
\hline $\begin{array}{l}\text { Capra hircus } \\
\text { Goat }\end{array}$ & $\begin{array}{l}\text { compressed, with } \\
\text { sharp inner edges in } \\
\text { front }\end{array}$ & - & 60 & 60 & $l \mathrm{~A}$ & $s \mathbf{M}$ \\
\hline $\begin{array}{l}\text { Capra ibex } \\
\text { Ibex }\end{array}$ & $\begin{array}{l}\text { I } 20.0 \mathrm{~cm} \text { fine, curved } \\
\text { corrugated }\end{array}$ & - & 60 & 60 & $l \mathrm{~A}$ & $s \mathbf{M}$ \\
\hline $\begin{array}{l}\text { Capra falconeri } \\
\text { Markhor }\end{array}$ & $\begin{array}{l}\text { long, spirally } \\
\text { twisted }\end{array}$ & - & 60 & 60 & $l \mathrm{~A}$ & $s \mathrm{M}$ \\
\hline $\begin{array}{l}\text { Ammotragus lervia } \\
\text { Aoudad }\end{array}$ & $\begin{array}{l}84.0 \mathrm{~cm} \text {, spread out, } \\
\text { back inward }\end{array}$ & - & $5^{8}$ & 60 & $l \mathrm{~A}$ & $s \mathrm{M}$ \\
\hline
\end{tabular}

* Similar to male. $2 n$ : Diploid Number; NF : Nombre Fondamental; A : Acrocentric; M : Metacentric; $s$ : Small; $m$ : Medium; $l$ : Large.

It has been postulated that the regressive evolutionary trend noted in mammalian $\mathrm{Y}$ chromosome might be the end result of conservation of only the essential male determining genes on the $\mathrm{Y}$ chromosome while the other once $\mathrm{Y}$-associated traits got eliminated, or translocated to autosomes through chromosome rearrangements. Thus, it is conceivable that certain aspects of male determinatior, probably the processes involving the early differentiation of the mesonephric blastema cells into Leydig cells, in goats are controlled by the autosome which we now recognize by its association with the polled trait. A similar situation has been demonstrated in Drosophila in which most of the male determining factors have been demonstrated to be on the second largest autosome (BEDICHEKPIPkIN, I959). Independent mutations on this chromosome have been reported to produce several less effective masculinizing genes. These mutant genes which are considered hypermorphic alleles of the normal male determining genes on this chromosome, have been shown to be ineffective on the $2 \mathrm{~A} / \mathrm{XX}$ female when they are in heterozygous states whereas in homozygous state they cause a complete sex reversal of the $2 \mathrm{~A} / \mathrm{XX}$ females into males (LEBEDEFF, I939; STUR'TEVANT I945). The polled allele may represent such a hypermorph mutation, the presence of which in homozygous condition causes the initial gonadal development in the male direction. The sterility noted consistently in $P P / \mathrm{XX}$ goat inter- 
sexes may be attributable to the absence of yet other genes which still remain on the $\mathrm{Y}$ chromosome and express themselves during spermiogenesis as in Drosophila (MEYER, I963) or during the earlier stages of spermatogensis.

The evolution of hornlessness (polled trait) in other members of Bovidae must have followed courses different from that of goats. The polled condition in certain breeds of domestic cattle, for example, is not known to be associated with intersexuality. It is worthy of note that the sex complements of members of Bovinae are strikingly different from that of Caprinae species (WURSTER, and BENIRSCHKE, I968). It is believed that goats which were domesticated before 3 ooo B.C., much earlier than cattle, are derived from the Chetan Ibex, Pasang or the wild goat (DRIMmER, I954). The striking karyotypic similarity between Caprine species and the successful intergenetic hybridization between members of Caprinae (Capra ibex $\times$ Capra hircus; Capra hircus $\times$ Ammotragus lervia) indicate that this subfamily has been cytogenetically very stable (HAUSCHTEK JUNGEN and MEILI, I967) whereas in Bovinae in which the " nombre fondamental" ranges from 38 to 62 (WURSTER and BENIRSCHKE, I968) autosomes as well as sex chromosomes seem to have been frequently involved in structural rearrangements.

Reçu pour publication en janvier 1970 .

\title{
ACKNOWLEDGEMENTS
}

The author is grateful to $\mathrm{D}^{\mathrm{r}} \mathrm{H}$. Kanagawa for his help and to the National Research Council of Canada for their financial assistance.

\section{RÉSUMÉ}

QUELQUES CONSIDÉRATIONS SUR L'ASSOCIATION DU CARACTÉRE MOTTE ET DE L'INTERSEXUALITÉ CHEZ LA CHÈVRE

\begin{abstract}
A la lumière des informations existant sur les intersexuées et la détermination du sexe, on a proposé le mécanisme cytogénétique suivant pour expliquer l'association du caractère motte et de l'intersexualité chez la chèvre d'élevage.

Sachant qu'il existe un dimorphisme sexuel des cornes chez les Bovidés les plus primitifs et que l'apparition des cornes est sous l'étroite dépendance des androgènes, on peut supposer que les facteurs déterminant la présence de cornes chez les espèces ancestrales de chèvres se retrouvent soit parmi les gènes du déterminisme mâle sur le chromosome $Y$, soit sont situés à proximité immédiate de ces derniers.

Chez les femelles des espèces de Bovidés plus récentes, la présence de cornes peut être attribuée à la translocation d'un segment du chromosome $Y$ sur un autosome.

Selon cette hypothèse, le développement des cornes et la différenciation des cellules somatiques du blastème en cellules de Leydig dans les testicules sont probablement contrôlés par le ou les mêmes gènes qui ont subi une translocation du chromosome $Y$ sur un autosome au cours de l'évolution de la sous-famille des Caprinés.
\end{abstract}

\section{REFERENCES}

BASRUR P.K., COUBrough, R.I., I964. Anatomic and cytogenetic sex of a Saanen goat. Cytogenetics, 3, $4 \mathrm{r} 4-427$.

BASRUR P.K., Stoltz D.R., I967. The Y chromosome of the goat. J. Hered., 58, 26I-262.

Basrur P.K., Kanagawa H, I968. Cytogenetic Studies on intersex goats (Abstract). Canad. J. Genet. Cytol., 10, 764 . 
BASRUR P.K., Kanagawa H., r969. Adrenal morphology and hydroxy steroid deshydrogenase enzymes in normal and intersex goats. Ann. Génét. Sél. anim., 1, 423-438.

Bedicher-PIPKIN S., 1959. Sex balance in Drosophila melanogaster. Aneuploidy of short regions of chromosome 3, using triploid method. Univ. Texas Publ., 5914, 69-88.

Drrmmer F., 1953. The animal Kingdom. Mammals, Birds, Amphibians, Reptiles. Vol. 2. Greystone Press. New York.

Hamerton J.I., Dixon J.M., Pollard C.E., Grieves S.A., ShorT R.V., r969. Genetic intersexuality in goats. J. Repr. Fert. Suppl., 7, 25-5I.

Hauschteck-Jungen F., MeIrI R., 1967. Vergleich der chromosomensatze von Steinwild (Capra ibex) and Hausziege (Capra hircus). Chromosoma, 21, 189- 210.

Heck H., Wurster D., Benirschke K., 1968. Chromosome Study of members of the Subfamilies Caprinae and Bovinae, family Bovinae; the Musk Ox, Ibex, Aoudad, Congo buffalo and Gaur. Sonderdrnck and $Z$. F. Saügetierkunde, 33, 172-179.

JACoBs P.A., Strong J.A., I959. A case of human intersexuality having a possible XXY Sex-determining mechanism. Nature, 183, 302.

Jost A., 1947. Sur les effets de castration précoce de l'embryon mâle du lapin. C. R. Soc. Biol., 141, I 26-1 29 .

I,auvergne J.J., 1969. Progrès des connaissances génétıques sur l'intersexualité associée à l'absence de cornes chez la chèvre d'origine alpine. Ann. Génét. Sél. anim., 1, 403-4I2.

L,EDEBEFF G.A., 1939. A study of intersexuality in Drosophila virilis. Genetics, 24, 553-556.

McFeely R.A., HARE W.C.D., BIGGers J.D., r967. Chromosome studies in $\mathrm{r}_{4}$ cases of intersex in domestic mammals. Cytogenetics, 6, 242-253.

Meyer G.F., 1963. Die Funktionsstrukturen des Y chromosomes in der Spermatocytenkernen von Drosophila hydei, D. neohydei, D. repleta und einigen anderen Drosophila-Arten. Chromosoma, 14, 207255 .

Neumann F., Eiger W., Steindeck A., I969. Drug-induced intersexuality in mammals. J. Repr. Fert. Suppl., 7, 9-24.

OrNo S. 1967. Sex chromosomes and sex-linked genes. Springer-Verlag, Berlin.

Soller M., Padeh B., Wysoki M., Ayalon N., I969. Cytogenetics of Saanen goats showing abnormal development of the reproductive tract associated with the dominant gene for polledness. Cytogenetics, 8, $5 \mathrm{I}-67$.

Sturtevant A.H., 1945. A gene in Drosophila melanogaster that transforms females into males. Gene tics, 30, 297-299.

WelshoNs, W.J. and Russell, I.B. (I959). The Y-chromosome as the bearer of male determining factors in the mouse. Proc. Nat. Acad. Sci. (Wash.), 45, 560-566.

WURSTER D.H., BENIRSChKe K., 1968. Chromosome studies in the super family Bovidae. Chromosoma (Berl.), 25, I52-171. 